UDK 781:78.082.1 Mahler

Niall O'Loughlin

Loughborough University

Univerza $v$ Loughboroughu

\title{
Interconnecting Musicologies: Decoding Mahler's Sixth Symphony
}

\author{
Muzikologije v prepletu: \\ Dekodiranje Mahlerjeve Šeste simfonije
}

Ključne besede: Gustav Mahler, Šesta simfonija, oblikovna analiza, programska glasba, glasbeno slikanje, glasbena biografija, glasbena narativnost

POVZETEK

Avtor želi razgrniti model večplastnega pristopa $\mathrm{k}$ razumevanju kompleksnega glasbenega dela. Za to uporabi vrsto med seboj povezanih muzikologij. V 19. stoletju so simfonijo pogosto šteli za abstraktno glasbeno stvaritev, v nekaterih primerih pa za programsko delo. Prve štiri simfonije Gustava Mahlerja so programske v tem, da tri med njimi vsebujejo uglasbeno besedilo, medtem ko je za vse štiri mogoče zlahka izvesti zunajglasbene interpretacije. Naslednje tri simfonije je mogoče različno razumeti kot abstraktne simfonije, ker so zveste vzorcu štiriali petstavčne cikličnosti, kjer so stavki med seboj kontrastni in nimajo eksplicitnega programa. V okviru tradicionalne muzikologije je mogoče $s$ formalnimi metodami analizirati in tako razumeti učinkovanje tematike in motivike ter sonatnega stavka, rondoja in scherza, vendar je iz študij nekaterih raziskovalcev razvidno, da imajo te metode samo omejeno uporabno vrednost. Vse tri simfonije namreč vsebujejo poteze, ki nakazujejo programske člene celo pri najbolj 'klasični' med tremi, pri Šesti simfoniji. Raziskave muzikologije glasbenega imaginarija tega dela, npr. motiv usode, udarci kladiva $\mathrm{v}$ Finalu, 'pastoralne' epizode in uporaba kravjih zvoncev indicirajo, da simfonija vključuje tudi druge sile. Da bi razbrali njihov delež, moramo gledati
Keywords: Gustav Mahler, Sixth Symphony, formal analysis, programme music, musical imagery, musical biography, musical narrative

SUMMARY

This paper aims to establish a possible model for a multi-dimensional approach to understanding a complex musical work, using a number of interconnecting musicologies. In the 19th century the symphony was often considered an abstract musical creation, but in other cases a programmatic work. The first four symphonies of Gustav Mahler are programmatic in that three set words to music, while extra-musical interpretations can easily be inferred for all four. The next three symphonies can be variously understood as abstract symphonies because they adhere to a pattern of four or five movements of contrasting character without any explicit programme. By using the musicology of traditional formal methods one can analyse and thus understand the workings of themes and motives and of the structures of sonata form, rondo and scherzo, but this seems in the studies of some commentators to have only limited application. All three have features which suggest programmatic elements, even the most 'classical' of the three, the Sixth Symphony. Investigations of the musicology of the musical imagery of this work, e.g. the Fate motive, the hammer blows in the finale, the 'pastoral' episodes, and the use of cowbells, indicate that there are other forces at work in the symphony. To un- 
v drugo smer, k drugim muzikologijam. Naslednja je biografska muzikologija, ki opozarja na skladateljeve težave pri vzpostavljanju zaporedja obeh srednjih stavkov - nekaj, kar ima veliko vlogo razumevanje pomena tega dela. Medtem ko je bil v partituri, ki je izšla pred prvo izvedbo, Scherzo pred Andantem, je Mahler spremenil njun vrstni red tako pri izvedbah, ki jim je dirigiral, kakor tudi v revidirani partituri. Njegovo sosledje je pri celotni ediciji zopet obrnil Erwin Ratz na podlagi precej pičlih razlogov in nekaj takih, ki so danes nesprejemljivi. Glasbeni razlogi so ostali, toda biografska pričevanja so tako močna, da so Ratzovi pogledi bistveno, če neže povsem ovrženi. Tonalitetni razlogi krepijo to pozicijo in omogočajo razumeti Mahlerjev načrt brez nejasnosti. Na tej točki se je mogoče obrniti k muzikologiji naracije. $Z$ muzikologijami tradicionalne analize, imaginarija, biografije in tonalitetnosti je mogoče nadalje obravnavati razvoj dela od začetka do konca. Na ta način se vsi deli povežejo v celoto in pokažejo v pravi luči, ki spodbuja k pozitivni interpretaciji prvih dveh stavkov, $z$ idilično situacijo na koncu prvega stavka, in pesimističnim rezultatom kombinacije zloveščega Scherza in prevzemajočega Finala. In končno, omenjene muzikologije bi bilo napačno razumeti kot medsebojno izključujoče se in nepomembne druga za drugo. Da bi največ zvedeli o večplastnem glasbenem delu, kakršna je Mahlerjeva Šesta simfonija, je bistvenega pomena, da upoštevamo vse postopke, in to ne vsakega posebej, temveč združene skupaj v koordinirano enoto. cover the implications of these we must look in other directions, to other musicologies. The next is biographical and points to some difficulty on the part of the composer to establish the order of the two middle movements, something which has a strong bearing on the overall meaning of the work. While the scherzo preceded the Andante in the score published before the premiere, Mahler reversed the order for all performances that he conducted and for the revised score. This order was reversed again by Erwin Ratz for the collected edition on some very slender evidence and some which is now discredited. Musical arguments have continued but the biographical evidence is so strong that Ratz's views are substantially if not totally undermined. Tonal evidence reinforces this position, making it possible now to understand Mahler's plan in an unambiguous way. At this point we can introduce the musicology of narrative. With the musicologies of traditional analysis, of imagery, of biography, and of tonality revealed, one can now proceed to investigate the progress of the work from beginning to end. In this way all the elements come into proper perspective with an overall plan suggesting a positive interpretation of the first two movements, with an idyllic situation at the end of the slow movement, and a pessimistic outcome of the combination of a sinister scherzo and overwhelming finale. In conclusion it is a mistake is to think that each of these musicologies presented here as mutually exclusive and of no significance to another. In order to derive the most from a multi-faceted work such as Mahler's Sixth Symphony, it is essential to take account of all these procedures, not singly but fused together as a co-ordinated unit.

This paper aims to establish a possible model for a multi-dimensional approach to understanding a complex musical work. The method is to use a number of interrelated musicologies or different aspects of the wide range of musicological disciplines to achieve this, thus avoiding the limitations and inconsistencies that are inevitable in a one-dimensional approach.

\section{Introduction}

In the early $19^{\text {th }}$ century, the symphony was considered an abstract musical creation usually planned in four contrasting movements. Certainly some composers continued this tradition, notably Beethoven, Schumann, Brahms, Dvořák and Bruckner. In the hands of some composers, however, such as Beethoven in his Pastoral Symphony, Berlioz, Liszt and Mahler, the abstract nature was often modified by extramusical elements and the programmatic symphony arose. In some cases composers 
published detailed stories or narratives to accompany performances of these works, but quite frequently these programmes were later withdrawn because they took the attention of listeners away from the music.

This is the situation in the case of the middle period symphonies of the Austrian composer Gustav Mahler (1860-1911). Mahler had composed his first three symphonies with detailed programmes which he subsequently withdrew, because they appeared to create the wrong response to his music. In the case of the Second and Third Symphonies, the words that he set in some of the movements gave some clue to a programme or perhaps even a 'meaning'. There is also the incorporation in these symphonies of various melodic elements from the songs that he set from the poetic collection Des Knaben Wunderhorn. The next symphony, the Fourth, belongs partly to this group, although the first three movements are part of Mahler's new trend, one that excludes specific programmes. The implicit programme of this symphony is not difficult to infer, because of the soprano's words in the finale and the thematic connections found in the earlier three movements. It is in the next three symphonies, the Fifth, Sixth and Seventh, however, that there is a tantalising ambiguity.

At first acquaintance the Fifth, Sixth and Seventh Symphonies are completely different from the earlier works. They are purely instrumental, with no vocal parts, either solo or choral, as there were in the previous three symphonies. Consequently they do not have words that suggest extra-musical meanings and do not have explicit programmes attached to them. They are laid out in a number of separate movements, either four or five, thus appearing to be planned in the abstract symphonic tradition. Indeed, numerous studies of these works base their arguments solely on this basis. There are some other accounts, however, that go to the other extreme, and relate the music to detailed programmes in much the same way as those that were published with works by Berlioz and even with Mahler's earlier symphonies. Can we find an approach to interpreting these works that encompasses the formal analytical studies as well as numerous other musical and quasi-musical features. It is this conflict which the present paper attempts to reconcile.

\section{Different Approaches}

In the first instance, it is the music itself which is the most important feature. With works such as those by Mahler, however, it is very revealing to investigate the extent to which his music goes beyond the abstract model towards programme music. In order to explore this properly, it is necessary to use not just one method, but a number of connected analytical musical or music-related disciplines. For the first method, we can employ the techniques of formal musical analysis to determine the musical events, their sequence and their relationship to the traditional model. Other forms of musical analysis can be of some help, too. The second is the use of musical imagery. In one way it can be seen as the use of melodic phrases from Mahler's songs and earlier symphonies; quotations and quasi-quotations from other composers' music; and generalised phrases which have been determined by composers' practice over the centuries. The other kind of musical imagery is more explicit, for example, the 
use of cowbells, marches of funereal character, parodistic dances, and birdsong. A third discipline that can be brought to bear on the 'meaning' of the music is biographical. With such an eventful and turbulent life such as Mahler's, it is not difficult to imagine that it affected his music in numerous ways. The fourth aspect that can be applied to these works is that of the study of musical narrative, the idea that a musical work can progress in the same or comparable narrative way as, for example, a novel. It is in this area that we can find a middle way between the principles of traditional abstract formal analysis on the one hand and the extra-musical elements thrown up by any ideas of programme. These interconnected 'musicologies' will all be drawn together to present an integrated viewpoint on a major work that dates from the first few years of the $20^{\text {th }}$ century.

\section{Formal Analysis}

Mahler's Sixth Symphony is considered the most 'classical' of his symphonies; it begins and ends in the same key, A minor, and it is nominally structured in the traditional four movements. The first three of these are considered 'regular' in their forms. The first movement has an identifiable sonata structure with two major thematic groups determined by key centres. Its exposition section is repeated, an unusual feature for an early $20^{\text {th }}$-century symphony. Its development section, recapitulation and extended coda follow an easily recognisable pattern. The slow movement is planned as a rondo in the contrasting key of $\mathrm{E}$ flat major. The scherzo in A minor with two trio sections, the first in $\mathrm{F}$ major and the second in $\mathrm{D}$ major would appear to be fairly normal. The finale, despite its length and complexity, can be related to the traditional sonata structure. It is made complicated by the appearance of a slow introduction which introduces each of the main sections in turn, by the fact that some of the second subject returns in the recapitulation before the first subject, and significantly by the sheer length of the movement (approximately 30 minutes).

It would be impossible in a short space to do justice to the observations made by many commentators and musicologists to the work. Their approach varies considerably. Erwin Ratz took a very straightforward view that the work, and in particular the finale, can be considered to be in the line of the Germanic abstract symphony. ${ }^{1}$ It follows all the standard forms of the genre (sonata form, rondo, scherzo and trio) in a way that can be fully appreciated by anyone familiar with these concepts. Even with the finale, Ratz found no difficulty in justifying his claim about the outstanding manipulation of form that the composer displayed by confining his analysis to the workings of the traditional concepts of formal working. This clearly has implications for his view the work as a whole. Peter Andraschke followed a very similar line of thought in his study. ${ }^{2}$ The more broad-ranging analysis and discussion by Henry

1 Erwin Ratz: 'Musical Form in Gustav Mahler: An Analysis of the Finale of the sixth Symphony', The Music Review vol.29 (1968), 34-48, translated from Die Musikforschung 9 (1956).

2 Peter Andraschke: 'Struktur und Gehalt im ersten Satz von Gustav Mahlers Sechster Symphonie', in Gustav Mahler, ed H. Danuser (Darmstadt: Wissenschaftlicher Buchgesellschaft, 1992), 206-237, reprinted from Archiv für Musikwissenschaft XXXV, 4 (1978), 275-96. 
Louis de La Grange ${ }^{3}$ are substantial and very informative in the same way that Ratz was. It takes account of many earlier analyses but stays generally within the area that Ratz charted.

Turning to other analyses, one notes in the more recent publications that there is a considerable questioning about the ideas of programme music and narrative. For example, Constantin Floros provided a very straightforward description that presents the work in generally abstract terms. ${ }^{4}$ However, in his introductory material, he questioned certain assumptions, and one in particular: 'Since numerous symbolic tonal features of the Sixth point towards programmatic intentions, it seems strange that the work has been widely regarded as absolute music. ${ }^{, 5}$ Because Norman Del Mar conducted the work on a number of occasions, his testimony can be seen to come from first-hand experience. His 'Thematic Analysis' ${ }^{\prime 6}$ and the 'Discussion and Analysis of Form" ${ }^{7}$ are presented in traditional terms that show the musical workings of the symphony in exemplary clarity. Yet Del Mar constantly hinted at programmatic elements in the work in the rest of his study. Hans-Peter Jülg made a very detailed study of the motivic workings in the symphony that can form the basis of any understanding of the intricate workings of the melodic material. ${ }^{8} \mathrm{He}$ also had certain reservations about ignoring the ideas of programmatic connections as can be seen in his extended discussion of the problem: is there a programme in the symphony or not?

\section{Musicology of Musical Imagery}

Mahler's Sixth Symphony, like the Seventh, has many instances of musical imagery. They appear in all the movements and are often connected to each other. In some cases the imagery is unambiguous, but in others it is less clear.

The most obvious and prominent 'event' is the so-called Fate motive, the sustained major chord which fades to a minor one. It seems to represent a move from optimism to pessimism. In the first movement Mahler used it prominently four times: at bars 59-60 (exposition repeated), in bars 203-11 (in the slower pastoral interlude), and in bars 334-35, but it also infiltrates the texture on a number of other occasions. It does not occur in the Andante, with major chords being sustained without change to the minor. In the scherzo the motive is played three times at the point of the collapse of the Scherzo proper, before the Trio, by the trumpets at bars 87-91, trombones and trumpet at bars 261-65, and the trumpets at bars 420-22 and in various versions in the bars following this passage. In the finale it appears ten times: at bars 9-12 (at the beginning of the introduction), bars 65-67 (after the chorale), bars 96-97 (just before

\footnotetext{
3 Henry Louis de La Grange: Gustav Mahler, Vienna: Triumph and Disillusion (1904-1907) (Oxford: Oxford University Press, 1999), 808-41.

4 Constantin Floros: Gustav Mahler: the symphonies (Aldershot: Scolar, 1994), 164-86.

5 Ibid. 162.

6 Norman Del Mar: Gustav Mahler's Sixth Symphony a study (London: Eulenburg, 1980), 23-33.

7 Ibid. 34-64.

8 Hans-Peter Jülg: Gustav Mahlers Sechste Symphonie (Munich: Katzbichler, 1986), 42-158.

9 Ibid. 13-17.
} 
the main Allegro moderato), bars 338-39 (on horns, just after the first hammer blow), bars 395-96, bars 401-2 (disguised), bars 530-335 (in return of introduction prefacing recapitulation), bars 668-70, bars 686-87, bars 783-89 (introduction before coda at the moment of third hammer blow). The last time the sustained triad on $\mathrm{A}$ is played (bars 820-21), it is in the minor only. Alongside this is the Fate rhythm on the timpani. Sometimes it appears just before the major-minor motive, sometimes at the same time and sometimes separately. It dominates the early part of the development of the first movement and underpins sections of the finale. These two materials have a chilling effect on the music and must surely have some significance in the way the music 'progresses'.

The main second main theme of the first movement was said by Mahler, as reported by his wife, Alma, to be a musical representation of her character. It seems that Alma was flattered by the tribute, as it has an exuberant character full of optimism and vitality. Its expansive arching melodies and yearning character and above all its emphatic major key make this one of the most positive elements in the movement. Inevitably this is seen to contrast with the determined minor-key march-like opening music of this movement. It is not difficult to relate this to the composer himself. Norman Del Mar had no doubts about its significance, 'And it required no great stretch of imagination to see the stormy but heroic material of the primary subject matter as a self-character-study'. ${ }^{10}$ It is interesting to note too that the two themes do have some parts in common, a feature also noted by some commentators. ${ }^{11}$ The return of this theme in the recapitulation is considerably abbreviated by Mahler, because he used it in the whole of the coda of nearly forty bars to exult in the most joyous way in the entire symphony.

There is a linking section between the two themes and the two fate motives, a chorale which first appears after the fate motive in the first movement (bars 61-76). It appears to have a mollifying influence on the march first theme, which now appears with the chorale in skeletal form, played pizzicato on the strings. After its reappearance in the repeated exposition, it immediately follows the major-minor motive twice in the pastoral interlude in the development section (bars 203-14) and on its own at the end of the closing section in E flat major (bars 239-42). The first four notes are used extensively in the rest of the development, while in the recapitulation the chorale appears mysteriously at double speed. In the Andante moderato the very brief return of the chorale from the first movement at bar 165 (Immer mit bewegter Empfindung) is surely poignantly significant. If the Andante were placed after the scherzo the significance of this reminiscence of the chorale would undoubtedly be lost. The chorale does not appear in the scherzo, but in the finale there are numerous chorales and some thematic material that has a clear connection with the chorale originating in the first movement. There is no obvious quotation of the four-note figure of the earlier chorale, but there is a significant quotation which has not been

\footnotetext{
${ }^{10}$ Norman Del Mar: Gustav Mahler's Sixth Symphony a study (London: Eulenburg, 1980), 16.

${ }^{11}$ David Matthews: 'The Sixth Symphony', The Mahler Companion, ed Mitchell and Nicholson (Oxford: Oxford University Press, 1999), 367; Hans-Peter Jülg: Gustav Mahlers Sechste Symphonie (Munich: Katzbichler, 1986), 52.
} 
mentioned by other commentators: at bars 49-64 a version of the chorale from the fifth movement of Mahler's Third Symphony is played, Schwer. Marcato (ungefähr l'istesso tempo). Is there any hidden meaning here?

Another element of musical imagery that Mahler used in the Sixth Symphony has received considerable comment: the use of cowbells. This has been justifiably related to the environment in which the work was composed, the countryside around the composer's summer residence near Maiernigg on the Wörthersee in Southern Austria. Their use in this symphony relates to the calm sections of the work. The passage in the development of the first movement (Allmählich etwas gehaltener, bars $196 \mathrm{ff}$ ) suddenly occurs, almost as if we emerged into a clearing (Adorno's expression is 'suspension'). The cowbells are meant to sound erratic, ${ }^{12}$ both high and low, sometimes close, sometimes far away. Mahler makes his intentions explicit: 'Die Herdenglocken müssen sehr diskret behandelt werden - in realistischer Nachahmung von bald vereinigt, bald vereinzelnt aus der Ferne herüberklingenden (höheren und tieferen) Glöckchen eine weidenen Herde ${ }^{, 13}$ Despite all this obvious 'picture-painting', the composer warns against reading too much into the passage: 'Es wird jedoch ausdrücklich bemerkt, dass diese technische Bemerkung keine programmatische Ausdeutung zulässt. ${ }^{14}$ The Andante moderato, with its invocation of a pastoral setting, is, not surprisingly, the next movement which includes the cowbells, while the Scherzo does not use them at all. In the finale, however, Mahler again suspends his main Allegro tempo, not only for the reappearance of the introductory passage but for a few bars beyond while the cow-bells make their appearance as a distant memory of the slow movement, before the main allegro tempo is restored (bars 229-59). Significantly the key is now D minor and not E flat major. The final appearance of the cowbells is surely the most poignant of all (bars 550-74). They emerge in a fragmentary texture after the introductory slow section together with the fate motive (major-minor chords, march rhythm) that introduces the recapitulation. The main allegro tries to start in fragmentary fashion but is interrupted by the mysterious chorale and the cowbells in a recollection of the pastoral section of the first movement and its full blossoming in the Andante. The key is again no longer the optimistic E flat major but the sinister $\mathrm{C}$ minor. This, despite the composer's warning against programmatic interpretations, must surely indicate the last fleeting memory of the idyll that might have been, before the final catastrophe descends.

Related to this is the particular importance of the key of $\mathrm{E}$ flat major and the way that the composer used it in this symphony. The Second Symphony, for example, begins in an unambiguous $\mathrm{C}$ minor but reaches $\mathrm{E}$ flat major in the finale to mirror the idea of resurrection. E flat major is the key of his most unashamedly optimistic work, the Eighth Symphony, which exults and reaches a form of redemption in the closing scene of Goethe's Faust Part II. In the Sixth Symphony, this is the key of the pastoral

\footnotetext{
${ }^{12}$ While rehearsing the percussion players of the BBC Symphony Orchestra at the Edinburgh Festival 2 September 1963, Norman Del Mar was having problems with the cowbell player who was playing in time with the orchestra and not rhythmically independently (personal observation).

${ }^{13}$ Gustav Mahler: Symphonie Nr.6 in vier Sätzen für großes Orchester (Lindau-Bodensee: Kahnt, 1963), 35.

${ }^{14}$ Ibid. 35.
} 
episode in the first movement, and the key of the whole of the Andante moderato slow movement. It is perhaps of some importance to the impact of this movement that it ends with a sustained and unwavering chord of $E$ flat major. However, in the two passages in the finale in which he also uses the cowbells, the keys are D minor and $\mathrm{C}$ minor, a significant change from the key in which the cowbells have previously appeared. The question arises as to why Mahler did this.

The Scherzo in Mahler's Sixth Symphony presents a particular problem. While it stands as an independent movement, it appears to parody the key structure of the first movement. ${ }^{15}$ This can be seen to relate to the first and second main themes of the first movement, which in the exposition are in A minor and $\mathrm{F}$ major and in the recapitulation in A minor and D major. This appears to be a somewhat simplistic view of the music. Four main points should be noted. The development of the first movement includes, as we have seen, a substantial section in the remote key of $\mathrm{E}$ flat major which has no place in the scherzo; the recapitulation starts, not very securely admittedly, in A major; the second theme in the recapitulation is deliberately abbreviated substantially in its appearance in D major; the second theme reaches its real climax in the coda where it is emphatically in A major. The A minor of the final appearance of the Scherzo differs fundamentally, of course, from the A major here. The character of the scherzo parodies the march-like first theme of the first movement, the three in a bar and the many offbeat accents, as well as the vivid and biting orchestration, emphasising this point. The trio, marked Altväterisch, is deliberately laboured and irregularly barred. It was said to represent children at play by Mahler to his wife. ${ }^{16}$ Thus this shows a completely different character from that in the 'Alma' theme of the first movement. The way that the movement progresses is particularly relevant. The main scherzo section is progressively reduced in length at each appearance, ${ }^{17}$ each time breaking off with the appearance of the A major-minor chord. The complete collapse at the end of the movement (from bar 409 onwards) into a series of fragments and whimpers is so evocative that one can hardly take it at face value. The question that can then be asked: what is the position of this parody in the symphony itself? Does it follow the first movement as a distorted mirror or should it set in motion a pessimistic viewpoint after the idyll of the slow movement?

The finale, despite its structural complexity, does not present the same difficulties. Some of the imagery found in this movement has already been discussed, the appearances of the major-minor chords, the minor keys of the cowbell passages, the mysterious chorale from the Third Symphony (related to the words Es sungen drei Engel). The most talked about aspect is the use of the hammer blows. The two that remain in the Internationale-Gustav-Mahler Gesellschaft score (bars 336 and 479) certainly appear to cause a great deal of excitement in the music. The third one at bar 783 was removed by Mahler after the first performance, although in this position,

\footnotetext{
${ }^{15}$ The keys of the first four sections, A minor, F major, A minor, D major, relate to the keys of the first movement's exposition's first theme and second main theme, and the first and second theme in the recapitulation, respectively.

${ }^{16}$ Alma Mahler: Gustav Mahler: memories and letters (London: John Murray, 3rd edition, 1973), 70.

17 Niall O'Loughlin: 'The Rondo in Mahler's Middle Period Symphonies', Muzikološki zbornik 35 (1999), $136-37$.
} 
when it would be played simultaneously with the beginning of the major-minor chords and the fate rhythm, it has a special significance. As a preface to the doom-laden coda, its meaning is unmistakable. The minor key chord in the final bars makes a most obvious contrast to the major key chord that ended the Andante moderato.

\section{Biographical Musicology}

We can now turn to thirds of the connected musicologies, biographical. Mahler composed the middle movements of the Sixth Symphony at his country retreat at Maiernigg on the Wörthersee in the summer of 1903. It seems that he also sketched some of the first movement during the same period. The opening movement and the finale were composed in draft form the following summer. The autograph score was ready in May 1905 for the copyist, with the Scherzo placed before the Andante. The score was published in this form some three months before the premiere in Essen in May 1906. However, in the final rehearsals in Essen, Mahler reversed the order of the middle movements for the first performance. He immediately issued instructions for a correction slip to be inserted into the remaining unsold copies of the published scores and prepared a new edition to take account of the movement order and the revised orchestration. All the performances in Mahler's lifetime, whether conducted by him or not, adhered to this order. Mahler had discussed the symphony in 1907 with his friend the Dutch conductor, Willem Mengelberg, who performed the Sixth Symphony in 1916 with the Andante-Scherzo order. For reasons that may be connected with the existence of copies of the uncorrected first edition study score of the symphony, in 1919 Mengelberg wanted to check that Andante-Scherzo was really the correct order. ${ }^{18} \mathrm{He}$ contacted the composer's widow who sent a famous telegram on 1 October 1919 saying 'Erst Scherzo dann Andante herzlichst Alma'. ${ }^{19}$ We do not know whether this represents the composer's last thoughts on the issue, which is possible but otherwise totally unsubstantiated, or whether this represented her own opinion as to how the music should be performed, which is possible in view of the conflict with her husband's apparently firm position as established by the performances and publication. It, of course, contradicts her statement Gustav Mahler: memories and letters that the Scherzo was the third movement. ${ }^{20}$ On the strength of this telegram, Mengelberg marked his score 'Nach Mahlers Angabe II erst Scherzo dann III Andante ${ }^{, 21}$ and performed it accordingly in 1920. Virtually all performances from then on, however, followed the revised published order of movements (AndanteScherzo), in public performances and recordings until the late 1950s when Erwin Ratz cast some doubt on the authenticity of this order.

\footnotetext{
${ }^{18}$ Jerry Bruck: Undoing a "Tragic" Mistake: Determining the inner-movement order of Mahler's Sixth Symphony, (New York: Kaplan Foundation, 2002). I am very grateful to Mr Bruck for allowing me to read his paper in advance of publication.

${ }^{19}$ Henry-Louis de La Grange: Gustav Mahler, Vienna: Triumph and Disillusion (1904-1907) (Oxford: Oxford University Press, 1999), 815.

${ }^{20}$ Alma Mahler: Gustav Mahler: memories and letters (London: John Murray, 3rd edition, 1973), 70.

${ }^{21}$ de La Grange: Ibid., 815.
} 


\section{Order of the Middle Movements}

Ratz put his ideas into concrete form with his edition of the work for the Internationale Gustav-Mahler-Gesellschaft Critical Edition of 1963, placing the Scherzo before the Andante. ${ }^{22}$ Because of the authority that this edition established, it has become normal for the work to be performed with the Scherzo before the Andante, even if some conductors dissented from this view. ${ }^{23}$ In his Revisionsbericht to the score, Ratz offers the following provocative remark: 'Eine weitere Änderung gegenüber der leider bisher geübten Praxis betrifft die Reihenfolge der Sätze. ${ }^{24}$ In other words he is casting doubts on the order that Mahler always chose for his performances, emphatically authorised for his printed scores and never changed in his lifetime. By way of evidence he makes an unsubstantiated supposition: 'Mahler aber erkannte sehr bald, daß damit die dem Werk zugrunde liegende idee zerstört was und stellte die ursprüngliche Reihenfolge (1. Satz, Scherzo, Andante, Finale) wieder her. ${ }^{, 25}$ In effect Ratz knew better than Mahler did about how he wanted his music to be played.

This position was emphatically supported by Theodor W. Adorno, who made the following statement: 'The conductor's productive irritability may have been irked by some ossifying details in the Sixth, above all the Scherzo; he was never entirely satisfied with the published version and revised the instrumentation extensively; his last arrangement of the movements, with the E-flat major Andante before the Finale, should be respected, if only for the modulation scheme; E-flat major is the relative of $\mathrm{C}$ minor, with which the Finale begins, only to decide, after long preparation, on A minor as its principal key. ${ }^{26}$ This is riddled with mistakes and unfounded suppositions. The remark about the conductor has no basis in fact and Mahler's lack of satisfaction with the published version was with the orchestration, as was normal with Mahler, not with the order of movements. Adorno assumes that the Scherzo-Andante order was his last arrangement of the movements when it was not, as Mahler adhered to the Andante-Scherzo order in his Vienna performance and never gave instructions to anyone to change this. The statement about key relationships involving major keys and relative minors has more to do with Beethoven than Mahler. The latter found much greater interest in mediant relationships and major-minor relationships involving the same tonic. Finally the statement about long preparation for A minor is confusing - Mahler arrives at A minor after only nine bars and then moves to $\mathrm{C}$ minor for a long section before the main Allegro in A minor.

Further support for this position is provided by Peter Andraschke in his article on the finale of the Sixth Symphony, in which he does attempt to tackle the problem with some rigour. In the part of his article entitled 'Exkurs III: Die Retuschen Mahlers an seiner 6. Symphonie, ${ }^{27}$ Andraschke relates the remarks by Klaus Pringsheim about

\footnotetext{
${ }^{22}$ Gustav Mahler: Symphonie Nr.6 in vier Sätzen für großes Orchester (Lindau-Bodensee: Kahnt, 1963).

${ }^{23}$ Norman Del Mar and John Barbirolli and more recently Simon Rattle, Glenn Cortese, Leonard Slatkin and James Judd.

${ }^{24}$ Mahler: loc. cit.: Revisionsbericht.

${ }^{25}$ Ibid. Revisionsbericht.

${ }^{26}$ Theodor W. Adorno: Gustav Mahler (Chicago: Chicago UP, 1992), 85.

${ }^{27}$ Peter Andraschke: 'Struktur und Gehalt im ersten Satz von Gustav Mahlers Sechster Symphonie', in Gustav Mahler, ed H. Danuser (Darmstadt: Wissenschaftlicher Buchgesellschaft, 1992), 234-37.
} 
Mahler's uncertainty at the rehearsals for the premiere as some evidence for the uncertainty. He points to the Dirigierpartitur of the Zweiter Fassung having tempo markings which contradicted the movements in the score. This score seems to be the one which Mahler used to conduct the first performance and is not the score that Andraschke identifies. His musical arguments to using Ratz's order are four in number:

1. Ending the first movement in A major and starting the Scherzo in A minor would mirror the way the motto moves from major to minor.

2. As the pastoral episode in the first movement relates to the Andante, the Andante should lie in the middle of the work, i.e. as the third movement

3. The $\mathrm{E}$ flat of the Andante relates better to the $\mathrm{C}$ minor at the beginning of the Finale.

4. The contrast between the movements is better effected by the Scherzo-Andante order.

The first argument is ingenious but difficult to support. The major-minor change in the symphony is effected by sustained chords with a lowered third. The first movement ends with a short quaver and the Scherzo starts with low As from timpani and string basses without a sustained A minor chord. The arguments of the second and fourth are highly subjective and hardly convincing. The third was the point that Adorno made. The appearance of $\mathrm{C}$ and $\mathrm{A}$ at the end of the Scherzo effectively links this with the finale's two opening keys of $\mathrm{C}$ minor and A minor. The relationship between $\mathrm{E}$ flat major and $\mathrm{C}$ minor was not a normal part of Mahler's key relationships.

Kark Heinz Füssl repeated a number of similar points, but there enters into his discussion a new layer of alleged uncertainty. Of the middle movements' order, he says: 'It remains something of a mystery why their reversal took place several times; it is as if Mahler... could not make up his mind which ordering would give the better, more effective rendering of the work. ${ }^{28}$ Did the reversal take place several times? The evidence suggests that it was once only. He makes the point: 'The Scherzo continues in the spirit of the first movement but does not act simply as a variation of it. ${ }^{29}$ In actual fact the first movement moves in exactly the opposite direction to the Scherzo. The former goes from a rather grim march to end in an exuberant A major, while the Scherzo stays firmly in the minor, gradually contracting and ending each of three times with the fate motive. Its final collapse into whimpering fragments prepares us perfectly for the heroic struggle and ultimate failure in the finale. Henry-Louis de La Grange follows Füssl in broad outline, being convinced that Mahler was persuaded, by implication against his better judgement, by those around him to change the order at the time of the first performance. ${ }^{30}$ This last is a highly subjective view which appears to derive from Mahler's highly emotional state at the time of the final rehearsals in Essen. ${ }^{31}$ There is no doubt at all that Mahler was distraught at the time of the first performance and that

${ }^{28}$ Karl Heinz Füssl: 'On the Order of the Middle Movements in Mahler's Sixth', News About Mahler Research (Vienna: International Gustav Mahler Society, March 1992), 5.

${ }^{29}$ Ibid. 6.

${ }^{30}$ Henry Louis de La Grange: Gustav Mahler, Vienna Triumph and Disillusion (1904-1907), vol 3 (2000), 815-16.

${ }^{31}$ Alma Mahler: Gustav Mahler: memories and letters (London: John Murray, 3rd edition, 1973), 99-100; Henry Louis de La Grange: Gustav Mahler vol 3 (2000), 410-12. 
he was unhappy with some matters, but to infer that he was ready to respond to pressure is unjustified. David Matthews believes that the A minor movements create a more powerful effect if they are played directly after one another. ${ }^{32}$

If this were simply an instant reaction to the situation, why did Mahler then instruct his publisher to change the order permanently, a complicated and costly operation? Why too did he continue to perform the work in Munich and Vienna, and allow it to be performed in Berlin, with the same order of movements? Surely we must look to the cumulative performing experience of the rehearsals in Essen in the days preceding the first performance to determine why the change was made. It must have been the experience of how the work really sounded that may well have convinced Mahler that he had finally chosen the better order for the middle movements. At this stage we must also now begin to question the propriety of these various musicians in presuming to correct a composer's clearly defined intentions, as shown in both performances and publications. A large number of people, following Ratz, presume to know the composer's intentions better than he did.

The opposite case has been taken by Deryck Cooke, ${ }^{33}$ Norman Del Mar, ${ }^{34}$ Christopher Hailey ${ }^{35}$ and Jerry Bruck, ${ }^{36}$ as well as by conductors. Eduard Flipse, Dmitri Mitropoulos, Charles Adler, William Steinberg, Sir John Barbirolli and Norman Del Mar who always performed the work in the published order. ${ }^{37}$ Simon Rattle continues to do so. Of course, only Barbirolli and Del Mar knew of the new Ratz edition, which has been the standard one available to Rattle. In his book on the Sixth Symphony Del Mar went out of his way to state his view that the correct order of movements was that found in the revised Kahnt edition of 1906. His justification for this view still carries weight today 'For Mahler's reaction, even during rehearsals, had been to realise that the Scherzo was too similar in style and dynamism to follow directly upon the enormously strenuous twenty-two-minute opening movement. Equally, for the Andante to precede the long slow introduction that opens the monumental Finale was not really satisfactory, whereas by reversing the order the necessary contrast and relief on both counts was solved at a single stroke. ${ }^{38}$ It would seem likely that his experience of conducting the work on a number of occasions was similar to that of Mahler. David Matthews challenged this view, thinking that it removed the prophetic power of the work, ${ }^{39}$ although as he admits, it is only speculation. My view is that it does quite the opposite.

32 David Matthews: 'The Sixth Symphony', The Mahler Companion, ed Mitchell and Nicholson (Oxford: Oxford University Press, 1999), 366-375.

33 Deryck Cooke: Gustav Mahler, an introduction to his music (London: Faber, 1980), 87.

${ }^{34}$ Norman Del Mar: Gustav Mahler's Sixth Symphony a study (London: Eulenburg, 1980), 89-92.

35 Christopher Hailey: 'Structure and Tonal Plan in Mahler's Sixth Symphony', Gustav Mahler, ed. H Danuser (Darmstadt: Wissenschaftlicher Buchgesellschaft, 1992), 253-75.

${ }^{36}$ Jerry Bruck: Undoing a "Tragic" Mistake: Determining the inner-movement order of Mahler's Sixth Symphony, (New York: Kaplan Foundation, 2002).

37 It seems that Mitropulos did in fact follow Ratz's suggestion in his performance in the late 1950s and played the Scherzo before the Andante at that time.

${ }^{38}$ Norman Del Mar: Ibid., 90.

39 David Matthews: 'The Sixth Symphony', The Mahler Companion, ed Mitchell and Nicholson (Oxford: Oxford University Press, 1999), 372-74. 
Christopher Hailey charts a very convincing large-scale tonal scheme that makes a great deal of sense of the order that Mahler always used for his performances. He connects, inter alia, the idyllic E flat major episode in the development of the first movement with the key of the Andante, and catalogues numerous motivic connections between the two movements. ${ }^{40}$ The implication is that the two belong together. Hailey interestingly relates and interprets the motivic connections between Andante and Scherzo in two ways ${ }^{41}$ depending on which order is chosen, even if he gravitates strongly towards placing the Andante first. He pertinently comments: 'Anything following the first movement will take on the quality of an intermezzo, ${ }^{42} \mathrm{a}$ view which is not completely consistent with the ideas put forward in this paper. The motivic and tonal relationships between Scherzo and Finale are even more important. ${ }^{43}$ Despite putting a very strong case Hailey maintains an open mind: 'While I would argue on esthetic grounds for an Andante-Scherzo ordering, it is not a question that can be resolved with complete satisfaction' ${ }^{44}$ Christopher Hailey's tonal evidence substantially undermined the stand taken in the complete edition and put considerable doubt on the rather glibly accepted orthodoxy of Erwin Ratz and Adorno.

The problem then can be summed up as follows: on the one hand, the AndanteScherzo order was maintained by Mahler in all performances he conducted to the end of his life and in all the publications after the first; on the other hand, the Scherzo-Andante order has been championed in retrospect by others who seem to know Mahler's mind better than he did. In other words, there is strong circumstantial evidence to support the former: to parody Alma Mahler's words 'Erst Andante dann Scherzo'. The case for the other point of view rests by and large on subjective ideas and hypothetical suggestions.

\section{The Musicology of Narrative}

Much has been written on the subject of musical narrative in recent years. In Mahler's case the writings of Adorno have usually formed the basis of discussions about his music. 'It is not that music wants to narrate, but that the composer wants to make music in the way that others narrate ${ }^{, 45} \mathrm{He}$ continues: 'The movement of the musical concepts begins... with the facts of experience, transmitting them in the unity of their succession and finally striking from the whole the spark that leaps beyond the facts. ${ }^{46}$ 'Mahler works decisively toward the abolition of tradition.' 'However, he does not construct new forms, but sets neglected, despised, rejected ones in motion. ${ }^{47}$

\footnotetext{
${ }^{40}$ Christopher Hailey: Ibid., 265-66. Some of these connections are given by Robert Samuels: Mahler's Sixth Symphony (Cambridge: Cambridge University Press, 1995), 26.

${ }^{41}$ Hailey: Ibid., 266.

42 Ibid., 267.

43 Ibid., 267-68.

${ }^{44}$ Ibid., 268.

45 Theodor W. Adorno: Gustav Mahler (Chicago: Chicago UP, 1992), 62.

46 Ibid., 62 .

47 Ibid., 62 .
} 
This in many ways sums up the problem of musical narrative in Mahler's Sixth Symphony. On the one hand, the work is considered the most 'classical' of the symphonies; it begins and ends in the same key and it is nominally structured in the traditional four movements. The first three of these are considered 'regular' in their forms and proportions and the finale, despite its length and complexity, can be related to the traditional sonata structure. Appearances are, however, deceptive, because on the other hand, there is without doubt a personal involvement in the music that has a strong bearing on certain details. The work is in some sense abstract in content, but it has a powerful emotional tone that constantly suggests an extra-musical meaning. The movements are filled with a great number of examples of musical imagery which add a new layer of interpretation to the progress of the work and at the very least undermine its sometimes supposed status as a 'pure' symphony. One wonders whether Mahler's emphatic denial of any programmatic interpretation is to be taken seriously. ${ }^{48}$ It is more likely that he did not want some kind of simplistic programme being affixed to the work, thus reducing the music to mere picture painting. This desire by critics and audiences to have a programme to use to follow the work was a problem that dogged him for most of his composing career, not least in America in his last years. The truth probably lies somewhere in between musical narrative and programme music, but we must ensure that neither interpretation detracts from the music itself.

To investigate the narrative of the middle-period symphonies it is helpful first to consider the earlier Fifth Symphony, about whose order of movements there is no controversy. It is generally agreed that in some way the work moves from darkness to light. Part 1 (the first two movements) comprises a grim funeral march interleaved with fast, violent and explosive sections in an interconnected series of recurring minor-key sections, which reach their climax in the D major chorale near the end of the second movement that momentarily expresses some kind of triumph. ${ }^{49}$ At this point the D major tonality is not sustained and the music collapses back into A minor in some kind of 'failure'. The Scherzo of Part 2 reintroduces D major in an exuberant dance-related context. Part 3 (Adagietto and Rondo-Finale), almost exclusively in major keys, presents another interlinked series of three 'rondo' materials: the middle section of the Adagietto and its related grazioso of the finale; the finale's main rondo theme itself; and the five fugal episodes. ${ }^{50}$ As in part one the music reaches a climax in the appearance of the $\mathrm{D}$ major brass chorale. In contrast to the collapse in part one, the music remains firmly anchored in D major right up to its triumphant conclusion. The narrative relates to the significance of major and minor keys, and the opposition of the march to the dance. The work in broad terms tries to achieve some kind of 'victory'. In the first instance, through the funeral march and the wild episodes, it is unsuccessful. After the invigorating experience of the scherzo, the following Ada-

\footnotetext{
${ }^{48}$ Hans-Peter Jülg: Gustav Mahlers Sechste Symphonie (Munich: Katzbichler, 1986), 13.

${ }^{49}$ Niall O'Loughlin: 'The Rondo in Mahler's Middle Period Symphonies', Muzikološki zbornik 35 (1999), 143.

${ }^{50}$ Niall O'Loughlin: 'The Rondo in Mahler's Middle Period Symphonies', Muzikološki zbornik 35 (1999), 143-44.
} 
gietto and Rondo-Finale lead the music to a second attempt, now successful, to reach a sustainable D major climax.

The process or narrative of the Sixth Symphony works the other way round. The first part can be seen to be positive, despite the appearance of disruptive or negative elements; the second part can be seen to be parodistic, negative, cynical and despairing. Despite positive and defiant elements, especially in the finale, it ends ultimately in some kind of 'disaster'. Of course, this scenario begs two questions. It assumes that the Andante precedes the Scherzo, and that the work divides into two parts, each of which consists of two movements. Mahler never explicitly divided the work into two parts, but nevertheless many commentators have preferred to think of it in two parts with the first three movements balancing the third. If one considers the actual durations of the movements, this would mean that part 1 would be nearly twice as long as part 2 , a fact that would counter the idea of balance. More plausible and of balanced duration is the suggestion that it is in three parts, the first movement, the two middle movements, and the finale, even if no rationale is given for this division. The third choice of two parts, each of two movements has not been seriously considered, but to take part 1 as Allegro energico and Andante, and part 2 as Scherzo and Finale does produce two approximately equal durations.

To determine why the Andante-Scherzo order is so compelling on a narrative level, we must look at the detailed operations of each of the movements and seek to explain why Mahler finally settled on a specific order. This is done simply to explain the rationale behind Mahler's choice and give some idea why he dispensed with the Scherzo-Andante order in his performances and in all but the very first printing of the first edition of the printed material.

A good place to start the investigation is with the element in the musical narrative for which we have firm evidence. The second main theme of the first movement was said by the composer's wife, Alma, to represent her in music. Its expansive arching melodies and yearning character and above its emphatic major key make this one of the most positive elements in the movement. Inevitably this is seen to contrast with the determined minor-key march-like opening music of this movement. It is not difficult to relate this to the composer himself. Norman Del Mar had no doubts about its significance, 'And it required no great stretch of imagination to see the stormy but heroic material of the primary subject matter as a self-character-study ${ }^{51}$ Interestingly the themes are related by common rhythms and melodic shapes. ${ }^{52}$ Separating these two elements in a relatively traditional sonata structure are the fate motifs, the rhythmic marching pattern and the major chord fading to a minor chord, followed by an ethereal chorale. It is no surprise that after the heavy impact of the fate motifs that the previously defiant 'Gustav' music appears together with this chorale but toned down to a gentle, skeletal pizzicato form, as an accompaniment. The 'Alma' theme then appears with incredible energy almost immediately.

\footnotetext{
${ }^{51}$ Norman Del Mar: Gustav Mahler's Sixth Symphony a study (London: Eulenburg, 1980), 16.

52 This is noted clearly by Andraschke, op. cit., Notenbeispiel 3, 222 and by David Matthews in The Mahler Companion, ed Mitchell and Nicholson (Oxford: Oxford University Press, 1999), 367.
} 
After the exposition is repeated, as Mahler instructed, the development produces some interesting juxtapositions. The rhythmic fate motif underpins the march-theme, almost as if it is transformed into something positive. The Alma theme is infiltrated into the textures until Mahler reaches the moment when time stands still (Allmählich etwas gehaltener) in the 'pastoral' episode. The major-minor fate motif and the ethereal chorale compete for our attention with intermittent cowbells and a new derivative of the Alma theme. Its ultimate destination is very significantly a firm and calm $\mathrm{E}$ flat major. Suddenly the vision is over with the tonality wrenched to B major with $\mathrm{E}$ flat becoming D sharp and the tempo restored to that of the opening and the character sehr energisch.

The music then strives for the moment of recapitulation, which significantly is momentarily in A major, but this reverts to A minor four bars later. The fate motifs are still present but the chorale is now doubled in speed. The Alma theme is gently introduced, unlike its explosive and dramatic interruption of the chorale in the exposition, but is very brief. The coda then passes through a wide range of key-centres (D major, E minor, E flat minor, $\mathrm{C}$ major, A major) with the Alma theme and its derivatives finally exulting in almost every possible way. Norman Del Mar's description exactly reflects the tone: 'Love has triumphed and from here to the end, all is jubilation'. ${ }^{53}$

It is not difficult to connect the Alma theme with that of the opening of the Andante moderato, the stepwise rising quavers, the melodic arch shape and the major key. It follows the first movement very naturally. This idyllic movement, following the major-key striving at the end of the first movement, mainly avoids minor keys, and banishes the fate motives and the defiant marching rhythms of the Allegro energico. Its constant return to the $\mathrm{E}$ flat major theme in a wonderfully varied number of guises must surely reflect in some oblique way the firm and stable tranquillity that Mahler was achieving in his family life (see Alma's memoirs). The very brief return of the chorale from the first movement at bar 165 (Immer mit bewegter Empfindung) is surely poignantly significant. What must decisively confirm the interpretation is that the E flat chord held in the horns at the end of the movement maintains its major tonality right to the last crotchet, without fading into the minor key.

The objections to the E flat major of the Andante following the A major of the first movement are surely irrelevant. There is no reason to worry about the change from A major to E flat major, because Mahler specified a pause between the movements. His instruction that the movements were not to be played attacca is clear: 'Nach jedem Satz findet eine kurze Pause statt'. ${ }^{54}$ With a pause of only a few seconds there is no problem for the listener to adjust to the new key. The $\mathrm{E}$ that sounds in the chord of A major at the end of the first movement is simply lowered by a semitone to the Eb that begins the Andante. We need only remind ourselves of the extreme key shifts that Mahler used in the first movement, e.g. A minor to F major from the chorale to the second main theme and from E flat major to B major to close the pastoral episode in the development. As mentioned earlier, Andraschke's suggestion that the change

\footnotetext{
${ }^{53}$ Norman Del Mar: Gustav Mahler's Sixth Symphony a study (London: Eulenburg, 1980), 41.

${ }^{54}$ Hans-Peter Jülg: Gustav Mahlers Sechste Symphonie (Munich: Katzbichler, 1986), 33.
} 
from the A major at the end of the first movement to the A minor of the Scherzo (if placed second) reflects the symphony's motto (A major-A minor) is ingenious, ${ }^{55}$ but would not be heard by the listener as a sustained chord that is transformed from major to minor.

Mahler was well aware from performances that he conducted of the parody that Berlioz employed in the last movement of his Symphonie fantastique, and, although he appeared never to have conducted it, he may well also have been familiar with Liszt's Faust Symphony with its third-movement parody of the first movement. It may be that this was carried over into Mahler's Sixth Symphony. Whatever the case the idea that the Scherzo is a parody of the first movement is undoubtedly true. The foursquare themes of the first movement are changed and distorted to fit a sinister threein-a-bar, with occasional extra beats, or, in the case of the Trio, some considerable irregularities in the metrical pattern. To make this happen before the appearance of the Andante moderato is undoubtedly to destroy the idyllic atmosphere anticipated by the positive and exultant coda of the first movement. To suggest that the audience's memory of the first movement would be lost during the serene moments of the Andante is to insult their intelligence. To put the Scherzo first and thus align it directly with the first movement, as David Matthews suggests, ${ }^{56}$ does reinforce the message of the scherzo, but to what purpose? Is there any point in parodying the first movement at this stage, before the pastoral scene anticipated in the E flat major episode of the first movement is reached? In Liszt's Faust Symphony there is no problem relating the parody third movement to the first, despite the intervening slow movement. It is more than likely that Mahler found this too in his rehearsals. Not quite in the manner of the Fifth Symphony, but in something of the same spirit, Mahler was looking prophetically, in the Scherzo and finale, at what might happen, having just explored in the first movement and the Andante what he hoped would be the case. All the positive elements of the Allegro energico and Andante moderato were perhaps an illusion. While the Fifth Symphony made one unsuccessful attempt to maintain D major, it succeeded the second time. In the Sixth Symphony (in Mahler's own performances), the first attempt to banish A minor (the 'danger' key of the Fifth Symphony) and hold on to A major and E flat major appeared to be successful. However, if he then ran through the materials of the first movement in a pessimistic way, A minor would have gained a firm hold. Despite the heroic efforts of the music of the finale, the alternative ending is bleak and unavoidable. In contrast with the sustained $\mathrm{E}$ flat major chord that concludes the Andante, the finale ends with the simultaneous rhythmic motto and an unambiguous A minor chord, without the linked A major chord.

Mahler's view would thus have been that the Allegro energico and Andante moderato represented his optimistic view of (his) life, while the Scherzo and finale the pessimistic (and ultimately realised) view of the course of the rest of his life. Is it no wonder then that, having chosen to perform the work with this order of movements,

\footnotetext{
55 Peter Andraschke: 'Struktur und Gehalt im ersten Satz von Gustav Mahlers Sechster Symphonie', in Gustav Mahler (ed H. Danuser) (Darmstadt: Wissenschaftlicher Buchgesellschaft, 1992), 234-37.

${ }^{56}$ Matthews: op. cit: 373-74.
} 
he was so emotionally shaken by the work? It remained for him somehow to exorcise this dread premonition in the next two symphonies. The Seventh Symphony attempted to use similar materials to create a new and much more optimistic intimate and personal interpretation on life, a view that I suggested recently ${ }^{57}$ and explored more extensively. ${ }^{58}$ The optimistic view presented in the Eighth Symphony is one that is less personal, and more universal, and shows that Mahler had succeeded in overcoming the inner personal concerns that he had and clearly had come to terms with his premature demise.

The narrative idea can be seen very clearly in the Fifth Symphony. We can take part one (movements 1 and 2) as an interconnected series of recurring minor-key sections, much of march-like character, which reach their climax at the D major chorale near the end of the second movement. It is the rondo-like elements that build up the tension and expectation. The music collapses into A minor in some kind of 'failure'. Part two (the scherzo) reintroduces $D$ major now in an exuberant dance-related context. Part three (Adagietto and Rondo-Finale), almost exclusively in major keys, presents another interlinked series of three 'rondo' materials: the middle section of the Adagietto and its related grazioso of the finale; the finale's main rondo theme itself; and the five fugal episodes. As in part one the music reaches a climax in the appearance of the same D major brass chorale. In contrast to the collapse in part one, the music remains firmly anchored in $\mathrm{D}$ major right up to its triumphant conclusion. The narrative relates to the significance of major and minor keys, and the opposition of the march to the dance.

In the Sixth Symphony the process is reversed, but in order to see the full significance of this, however, one must use the order of the middle movements which Mahler used at the first performance and for the revised publication. In this format the first two movements contain the triumphant climaxes, the third and fourth movements the collapses. The conflict between the A minor march material of the first movement (perhaps the 'Gustav' music) and the 'Alma' theme results in a triumph for the latter. The three appearances of the chorale in the first movement separated the two predominant themes. The return of the chorale at the climax of the almost totally major music of the Andante has some hidden significance. There are further links between the movements in that the 'pastoral' episode's main key (E flat major) foreshadows that of the Andante moderato.

The scherzo and finale now turn the triumphs on their head. The scherzo parodies the first movement, tonally, rhythmically and thematically. Its three-in-a-bar music sardonically mocks the march material, while the keys of the two trio sections ( $\mathrm{F}$ and D major) mirror in parodistic fashion the predominant keys of the positive 'Alma' music. The main scherzo section is progressively contracted at each appearance with a devastating collapse at the third time. As noted above, the collapse ends by emphasising the two notes A and C, significantly the key-notes of the two minor-key tonali-

\footnotetext{
${ }^{57}$ Niall O'Loughlin: 'The Rondo in Mahler's Middle Period Symphonies' Muzikolški zbornik 35 (1999), 144-45.

${ }^{58}$ Niall O'Loughlin: 'The Hidden Programme of Mahler's Seventh Symphony', (Keele: ESCOM, 2000); Muzikološki zbornik 36 (2000), 73-82.
} 
ties that dominate the early part of the finale which results in the biggest collapse in all of Mahler's music.

\section{Conclusion}

Mahler's symphonies are complex and often contradictory. Using the first musicology, it is possible to investigate and analyse the music in a traditional way in much the same manner as one would study a symphony by Beethoven. This has been done with great skill by such musicologists as Erwin Ratz. With the second musicology, however, one can observe so many different images suggesting some extra-musical meaning that it is impossible to ignore their significance. By co-ordinating these there is the implication of considerable programmatic evidence. By investigating the work using the biographical musicology, one can determine, among other things, the way Mahler wanted the music to be performed and consequently how the programmatic elements interact and develop. One can use the musicology of narrative to determine how the music progresses from beginning to end and understand in some way the message that Mahler was communicating. The mistake is to think that each of these musicologies is mutually exclusive and of no significance to another. In order to derive the most from a multi-faceted work such as Mahler's Sixth Symphony, it is essential to take account of all these procedures, not singly but fused together as a co-ordinated unit. 